\title{
Structural Limitations with K Means Algorithms in Research in Perú
}

\author{
Javier Pedro Flores Arocutipa ${ }^{1}$, Juan Luna Carpio ${ }^{5}$ \\ Universidad Nacional de San Agustín \\ Arequipa, Perú
}

\author{
Jorge Jinchuña Huallpa² \\ Universidad Nacional de Moquegua \\ Moquegua, Perú
}

\author{
Julio César Lujan Minaya ${ }^{3}$ \\ Universidad Nacional de Cañete \\ Cañete, Perú
}

\author{
Ruth Daysi Cohaila Quispe ${ }^{4}$ \\ Gamaniel Carbajal Navarro ${ }^{6}$ \\ Universidad José Carlos Mariátegui \\ Moquegua, Perú
}

\begin{abstract}
In the world of science there are high-level, moderate-level, and low-level emerging countries. The indicators are an investment in research and development (I\&D), number of universities, investment, researchers, intellectual production, expenditure on education, gross domestic product (PBI), and quality of life (IDH). In Methodology, it is basic, explanatory, of conglomerates. There are 37 countries analyzed. The data comes from the FMI, datosmacro.com, UNESCO, URWU. There are 11 indicators. These are data taken in two stages, 2006 and 2019. The Results shows $\mathrm{R} 2=\mathbf{0 . 9 8 8 7}$, which explains the behavior of the PBI by the investment in I\&D. The positive and significant relationship between IDH and PBI per capita, which is 0.824 , is transcendent. In conclusion, there are three clusters with clearly differentiated indicators. Peru's problem is structural in that it does not have a per capita PBI of $\$ \mathbf{3 0 , 0 0 0}$ per person or more. Investment in I\&D in Peru is low and PBI is also low. Therefore, countries with higher investments in science have high PBIs and better IDH.
\end{abstract}

Keywords-Researchers; PBIpc; investment in I\&D; exports; universities

\section{INTRODUCTION}

One thing that sets developed countries apart from nondeveloped countries in science and technology. This is what Francisco Sagasti, current president of Peru, reminds us [1] today, the production of vaccines against COVID 19 can only be produced by countries called "rich"? So should the longterm vision of Latin or African countries be rethought? The capacity of researchers? Resources for Research? And above all, the will of the state to achieve quality-of-life goals for its citizens? Underdevelopment and dependence are related [2] In the same way PBI and scientific production are related [3]. This document leads us to specify data and strategies to help us reflect on what needs to be done within the framework of social welfare.

The lack of vaccines shows the reality of the Peruvian state, the health crisis, the scientific infrastructure to confront the disease. The concept of a failed state was pointed out by the Ombudsman, who said, "the state is not up to the needs of Peruvian citizens" [4].
The experience of rapid testing revealed that not only was there no science, but strategic confusion to deal with evil. By failing to detect asymptomatic, rapid tests announced that only $2 \%$ of them had COVID [5].

Today there is a conviction that if there are no vaccines, the economy can't be reactivated. China demonstrates this growth in 2020 by $2 \%$; the world has recessed by $-4.5 \%$. Some countries face quickly and effectively, as of April 7, 2021, the portal [6] notes that Israel has already vaccinated $61.18 \%$ of its population, Chile 37\%, the United States 33\%, Peru 2\%.

Bill Gates, who has inside information, has said he should be surpassing COVID 19 by the end of 2022. Of course, he is thinking of developed countries. That phrase for Peru means 2024.

Our hypothesis is that emerging countries, such as Peru, have little chance of successfully dealing with any pandemic if they do not achieve a plan to achieve a per capita PBI over $\$ 30,000$, a developed country IDH, that their exports be of differentiated products, where qualified researchers are one thousand per million, accredited by CONCYTEC and the resources for research exceed 1000 dollars per person.

\section{Methodology}

Since 1993, we have observed and accumulated information on research resources, for education, by country, making statistical relations between the variables of analysis.

Data have been collected for the year 2006 compared to 2019, although there are 13 years of difference to assess that the reality has changed very little [1]. The World Bank, datosmacro.com, [7], the National Council for Science and Technology (CONCYTEC) [8] has been used to observe levels of explanation of the number of researchers and investment in $\mathrm{I} \& \mathrm{D}$, in addition to locating relationships between variables.

Variables have been grouped in annual PBI, in current terms, the number of universities by country, Human Development Index (IDH), PBI per capita, Per capita Expenditure Education, in dollars, Education Expenditure (millions), Exports (millions), Research (millions), research in science and technology per person (invCTporpers), 
Researchers per million inhabitants, indexed publications (Scopus) [8] per 100000 inhabitants.

How many researchers per million are there in Peru? Although in the CONCYTEC portal it can be read by March 31, 2021, that 5942 people have been qualified in the segments of Maria Rostorowski and Carlos Monge, and with that data, the location of Peru in the World Ranking is achieved. The Pearson correlation and determination coefficient is used.

\section{RESULTS}

Stage 1. (2006): In 2006, four variables were analyzed: investment in I\&D, PBI, exports, and the number of universities by macro-region of the world.

What was the situation in 2006 about the reality to be investigated? Gross domestic product per capita is vital for development. And it comes from the wealth generated by countries. Thus, North America had 47.5\% of the world's wealth, followed by the Asia Pacific with $25.5 \%$, in third place, Europe with 19.7\%, Latin America with 5.9\%, and Africa with $1.3 \%$ of the world's wealth. This means that Europe has a GDP of 4.5 trillion, North America 11 trillion, Asia Pacific 5.9 trillion, Latin America 1.37 trillion, Africa 0.3 trillion, with a world total of 23.2 trillion dollars.

In the world, in 2006, the region that achieved the best universities in the world was Europe. So of the first 500, she had 207, then there was North America with 189 universities, the Asia Pacific got the third place with 92 universities, Latin America only got 7, and finally Africa with 5 universities. It should be noted that, among the top 20 universities, North America had 17, or of the top 10058 were from North America, so, when the top 200 universities were counted, North America had 95 universities. And in the first 400 and 500 Europe regains its first place. It should be noted that the best universities are concentrated in the United States.

In 2006 (Table I), which is based on [9] [10] [11], 7.5 trillion were exported in the world, and $36 \%$ were concentrated in Europe with 2.7 trillion, North America with 29\% representing 2.2 trillion. The Asia Pacific had 28\% with 2.1 trillion, Latin America with 5\% with exports worth 375 billion, and Africa with $2 \%$ of total world exports.

It can be assumed that developed country exports differ from emerging country exports; while some export sophisticated products and others export raw materials [12]. And they are sophisticated products because there is a strong investment in research and development to achieve goods and services of high productivity and effectiveness with prices that allow selling volume with decreasing prices.

Over time, North America has achieved a higher percentage of investment in I\&D. Thus in 1994 the investment in C\&T represented $35.1 \%$ and in 2003 it was $41.9 \%$. However, Europe decreased, from $30.6 \%$ to $28.2 \%$, also the Asia Pacific regions from 31.3\% to 27.3\%, and Latin America from $1.6 \%$ to $1.3 \%$, and Africa plus Oceania from $1.4 \%$ to $1.3 \%$.

The results (Table II), the correlation coefficient of the variables analyzed indicates that, between the number of universities by region and the level of exports, is 0.94 , meaning that the regions that have more universities than their exports are greater and vice versa.

TABLE I. LIST OF VARIABLES FOR 2006

\begin{tabular}{|l|l|l|l|l|l|}
\hline Continents & $\begin{array}{l}\text { Univer } \\
\text { (a) }\end{array}$ & Expor(b) & $\begin{array}{l}\text { PBI } \\
\text { Real(c) }\end{array}$ & $\begin{array}{l}\text { InverI\&D } \\
\text { (d) }\end{array}$ & $\begin{array}{l}\text { PBI } \\
\text { EST (e) }\end{array}$ \\
\hline Europe & 207 & 2701 & 4591 & 242 & 6511 \\
\hline North America & 189 & 2178 & 11057 & 360 & 9549 \\
\hline Asía Pacific & 92 & 2100 & 5932 & 234 & 6305 \\
\hline Latín America & 7 & 375 & 1377 & 11 & 562 \\
\hline África & 5 & 150 & 300 & 2 & 330 \\
\hline
\end{tabular}

TABLE II. CORRELATION COEFFICIENT

\begin{tabular}{|l|l|l|l|l|}
\hline & Univer & Expor & PBI & InverID \\
\hline Universities & 1.00 & 0.94 & 0.78 & 0.91 \\
\hline Exports & 0.94 & 1.00 & 0.74 & 0.91 \\
\hline PBI & 0.78 & 0.74 & 1.00 & 0.95 \\
\hline I\&D investment & 0.91 & 0.91 & 0.95 & 1.00 \\
\hline
\end{tabular}

On the other hand, there is a high and significant relationship between the number of universities per region and investment in I\&D, which is $91 \%$. It turns out that PBI is associated with $95 \%$ investment in research and development, which is high and determining since it informs us that the greater the investment in I\&D the greater the PBI (wealth). Likewise, the regions that have greater exports are related to the regions that invest more in I\&D, this is 0.95 or $95 \%$. Countries that invest little in I\&D then their exports are smaller. And they export raw materials or very little differentiation.

When it is assumed that the dependent variable is prestigious universities, understand by internationalized [13] as part of the world, with a global or global vision, this depends on the following three variables: world exports, global PBI, and the resources allocated for research and development. This is deduced because the Pearson correlation exceeds the $74 \%$ that is high.

The ratio of wealth generated to investment in research and development, by region in the world, is $90 \%$. All this refers us to [14] which maintain that in A.L. despite the efforts of science in recent years has not given levels of satisfaction. There is no doubt that it could be improved, but for the time being, these are the results that can be observed.

In the Econometric Analysis 2006, based on the calculation in the Eviews Software, you will find the following model that explains the behavior: PBI $=278.955900199+$ $25.7505541802 * \mathrm{R} \& \mathrm{D}$ investment. That informs us that the level of explanation or R squared is 0.906 that the investment beta has a p-value of 0.01 that makes it very significant. In addition, the DW is 2.57 which is on the margins of 2 . It is a model that explains that the size of the wealth of regions depends up to $90 \%$ on investment in I\&D. It indicates the relationship between the behavior between the historical series and that calculated by the equation, which will allow us to 
affirm that in history the levels of explanation of I\&D, if it is related to the levels of wealth in the world (2006).

One question, what is the elasticity of investment in $I \& D$, in PBI growth by region? The statistical evidence indicates, the impact is, if investment in I\&D increases by $10 \%$, then wealth grows by 6\%; and in that way proportionally. The model is: $\log (\mathrm{PBI})=5.46+0.6047 * \log (\mathrm{I} \& \mathrm{D}$ inversion) with the $\mathrm{p}$ value for the coefficient of the variable is 0.0037 which signals that the coefficient is significant.

And with a Prob (F-statistic) of 0.0036 that indicates that the model is acceptable.

It is confirmed that the levels of economic growth should be higher than the growth of the SAP. With appropriate levels of technology and high productivity, it can enable improvements in the IDH [15] of citizens within a jurisdiction.

Therefore, economic growth is a good reason, as it happened in China, which, with rates between $7 \%$ and $11 \%$, [16] has managed to raise its PBI per capita from 1000 (1999) to 10 thousand euros in 2019.

State policies, prioritizing production, education, research, exports of sophisticated goods, the optimization of resources, and maximum productivity, could aspire to the development of our country. The author Quinde [17] carried out the mathematical analysis of the relationship between PBI and expenditure in science in Latin America, between the years 1990-2015, it turns out that for A.L. there are no levels of explanation or relationship but if for the country of Ecuador. To perform the demonstration, it uses the Granger causality test, cointegration, and the unit root test.

How was 2019?

13 years later. The ranking of researchers by countries of the world is associated with the ranking of PBI generated, at the top are the developed countries. In the world, there are TOP-countries in research, those that carry out average research, and countries that do little and little research [3] translated into scientific articles, patents, and innovations.

This is a strong correlation between the number of researchers per million inhabitants (NIPMH) per country and the PBI per capita. The number of scientific articles produced per 100,000 inhabitants to (NIPMH) per country. In (Table III) it is observed that in the first column there are 37 countries, in the second column the number of universities per country in the first 1000 in the world. Then comes the pc PBI. All of the following values are measured in euros. Except for the IDH. Looking at the averages of the variables exposed, it is observed that the maximum data for Peru are well below the world average.

At the end of 2020, Peru had 181 researchers per million inhabitants [12]. Perhaps they should be a little overjoyed, given that below Peru, there are, for example, India with 137 per million, Colombia 126, Bolivia 120, Paraguay 71, and Ecuador 69 per million. But at the same time, it should be worrying, that Israel, according to [10], has 8250 researchers per million inhabitants, and Finland, Iceland, are above 7305 per million inhabitants. The case of Singapore, Denmark,
Japan, Norway, Sweden, which are above 5200 researchers per million inhabitants, then the United States, the United Kingdom, Canada, Australia, which are above 4200 researchers per million inhabitants, would be Portugal, Germany, France, Switzerland, Belgium, Ireland with more than 3000 researchers per million and the block of Spain, Hungary, Poland, Italy, and China with more than 1000 researchers per million, also Argentina, Chile, Brazil, Cuba, Mexico, above 300 per million and then there would be Venezuela, Peru, India, Colombia, Bolivia, Paraguay, Ecuador above 69 per million but below 187 researchers per million.

Among the results, (Table IV) it can be noted that there is a positive relationship between wealth (PBI) of 37 countries and investment in (I\&D) in 2019. In that sense, an $\mathrm{R}$ of 0.983 was found, a very valuable relationship, that if countries have greater wealth then they would allocate in absolute terms a greater portion of resources for research. And vice versa to lower PBI then investment in (I\&D) will be lower. Another of the results (Table $\mathrm{V}$ ) is the positive and very high relationship between the NIPMH and PBI pc (0.7); with per capita expenditure on education (0.74); with investment in (I\&D) pc (0.828) and a positive relationship with publications per 100 thousand people in Scimago. In the same way, the scientific production measured by Scimago in the analyzed countries is related to their PBIpc (0.916) with the level of exports (0.642).

It is also imperative to note the number of universities per country is related and explains the investment in (C\&T) per capita by country. Here the R2 is 0.904 and the R of Pearson is 0.951, the higher investment, the greater number of universities ranked within the first thousand in the world. Similarly, spending on education correlates with the size of wealth per country with a fairly significant Rho of 0.9934. Here, Wagner's law seems to be adhered to, that the larger the size of the economy, the greater the public spending on education.

Universities are innovation center's that interpret productivity as the ultimate goal for competitiveness, [18] in that sense it has been found that the number of universities per country is related to export levels per country. They are the patents and research in science and technology that allows greater exports or vice versa greater number of universities in the world. Here the Rho is 0.843 is significant.

Indeed, the number of universities within the first thousand in the world is related to their respective PBI of the country. The Pearson Rho is 0.969. It means that if the PBI is high then the number of universities will also be high. It has been stated that exports of raw materials and sophisticated goods are one thing. It should be understood that developed countries or countries with a PBI above 30,000 dollars' per capita export sophisticated goods unlike countries of the second or third world. In this sense, it should not be overlooked that exports by country are significantly related to education spending by country. The Rho is 0.825 quite high and direct. It could not be overlooked that I\&D investment, research aims at differentiating products and services that make raising productivity improves competitiveness levels thus achieving a greater share (\%) of the markets, the relation with exports is 0.8 . 
TABLE III. RESUlTS PER UNIT

\begin{tabular}{|c|c|c|c|c|c|c|c|c|}
\hline Countries & Univ & IDH & PBI pc & $\begin{array}{l}\text { Expenditure pc } \\
\text { Education }\end{array}$ & Exports pc & Rese-arch pc & $\begin{array}{l}\text { Researchers } \\
\text { per million }\end{array}$ & $\begin{array}{l}\text { Scimago for } \\
100000\end{array}$ \\
\hline Israel & 7 & 0.919 & 39698 & 2070 & 5768 & 1928 & 8255 & 4451 \\
\hline Corea del Sur & 32 & 0.916 & 28472 & 2748 & 18871 & 2755 & 7980 & 2315 \\
\hline Finlandia & 8 & 0.938 & 43570 & 2864 & 11875 & 1206 & 7707 & 6508 \\
\hline Singapur & 4 & 0.938 & 58934 & 2293 & 61194 & 1130 & 6088 & 5568 \\
\hline Austria & 14 & 0.922 & 44780 & 2368 & 17929 & 1416 & 5733 & 4696 \\
\hline Dinamar-ca & 6 & 0.94 & 53760 & 3658 & 16997 & 1644 & 5670 & 7314 \\
\hline Japón & 40 & 0.919 & 35888 & 1069 & 4994 & 1173 & 5573 & 2293 \\
\hline Noruega & 5 & 0.957 & 67730 & 5549 & 17088 & 1397 & 5468 & 6327 \\
\hline Suecia & 14 & 0.945 & 46160 & 3567 & 13887 & 1534 & 5239 & 6817 \\
\hline EE.UU. & 206 & 0.926 & 58485 & 2497 & 4475 & 1655 & 4663 & 3909 \\
\hline Reino Unido & 65 & 0.932 & 37770 & 2138 & 6263 & 647 & 4269 & 5544 \\
\hline Canadá & 28 & 0.929 & 42048 & 1895 & 10505 & 643 & 4260 & 4939 \\
\hline Australia & 34 & 0.944 & 48969 & 2375 & 9495 & 902 & 4224 & 5837 \\
\hline Portugal & 6 & 0.864 & 20740 & 898 & 5823 & 284 & 3799 & 3243 \\
\hline Alemania & 49 & 0.947 & 41510 & 2048 & 15999 & 1282 & 3532 & 3875 \\
\hline Francia & 30 & 0.901 & 35960 & 1935 & 7575 & 793 & 3496 & 3341 \\
\hline Suiza & 14 & 0.955 & 76200 & 3853 & 32623 & 2559 & 3436 & 8880 \\
\hline Bélgica & 8 & 0.931 & 41460 & 2653 & 34645 & 1166 & 3435 & 4945 \\
\hline Irlanda & 5 & 0.955 & 72260 & 2358 & 30514 & 825 & 3090 & 4474 \\
\hline España & 40 & 0.904 & 26430 & 1103 & 6303 & 326 & 2944 & 3147 \\
\hline Rusia & 11 & 0.824 & 10346 & 343 & 2549 & 102 & 2784 & 819 \\
\hline Malasia & 5 & 0.81 & 9380 & 418 & 6542 & 134 & 2397 & 999 \\
\hline Polonia & 8 & 0.88 & 13870 & 662 & 6214 & 170 & 1623 & 1872 \\
\hline Italia & 46 & 0.892 & 29660 & 1140 & 7978 & 420 & 1616 & 3155 \\
\hline Irán & 12 & 0.783 & 4586 & 175 & 591 & 38 & 1475 & 698 \\
\hline Turquía & 11 & 0.82 & 8230 & 345 & 1820 & 24 & 1379 & 769 \\
\hline Tailandia & 4 & 0.777 & 6307 & 251 & 3159 & 61 & 1350 & 286 \\
\hline China & 144 & 0.761 & 9180 & 348 & 1594 & 200 & 1307 & 471 \\
\hline Argentina & 3 & 0.845 & 9028 & 505 & 1294 & 48 & 980 & 501 \\
\hline Chile & 4 & 0.851 & 13457 & 714 & 3258 & 47 & 833 & 856 \\
\hline Brasil & 22 & 0.765 & 7562 & 470 & 946 & 95 & 694 & 489 \\
\hline Egipto & 5 & 0.707 & 2231 & 69 & 257 & 15 & 687 & 229 \\
\hline México & 2 & 0.779 & 9090 & 373 & 3223 & 28 & 353 & 272 \\
\hline Pakistán & 4 & 0.557 & 1326 & 40 & 100 & 3 & 336 & 85 \\
\hline Perú & 0 & 0.777 & 5933 & 218 & 1310 & 8 & 181 & 91 \\
\hline India & 15 & 0.645 & 1741 & 62 & 212 & 11 & 137 & 137 \\
\hline Colombia & 1 & 0.767 & 5801 & 250 & 700 & 14 & 126 & 227 \\
\hline
\end{tabular}

TABLE IV. CORRELATIONS

\begin{tabular}{|l|l|l|l|l|l|}
\hline & Annual PIB & Universities & Education expenditure (millions) & Exports (million) & I\&D Invest. (millions) \\
\hline Annual PIB & 1 & 0.969 & 0.993 & 0.843 & 0.983 \\
\hline Universities & 0.969 & 1 & 0.973 & 0.843 & 0.951 \\
\hline IDH & 0.04 & 0.134 & 0.074 & 0.095 & 0.1 \\
\hline PBI Per cápita & 0.119 & 0.175 & 0.151 & -123 & 0.196 \\
\hline Per capita expenditure on education & -0.037 & 0.024 & 0.008 & -0.062 & 0.825 \\
\hline Expenditure on education (million) & 0.993 & 0.973 & 1 & 1 & 0.032 \\
\hline Exports (in millions) & 0.843 & 0.843 & 0.825 & 0.982 & 0.8 \\
\hline Research (in millions) & 0.983 & 0.951 & 0.982 & 0.034 & 1 \\
\hline Researchers per million inhabitants. & 0.042 & 0.102 & 0.06 & -0.143 & -0.027 \\
\hline Documents Scimago per 100000 & -0.044 & 0.052 & -0.004 & 0.02 \\
\hline
\end{tabular}


TABLE V. CORRELATION OF PEARSON WITH 37 DATA

\begin{tabular}{|c|c|c|c|c|c|c|c|}
\hline & University & PBI pc & $\begin{array}{l}\text { Gasto pc } \\
\text { education }\end{array}$ & Exportpc & $\begin{array}{l}\text { Investigation } \\
\text { I\&D pc }\end{array}$ & $\begin{array}{l}\text { Imvest por } \\
\text { million hab }\end{array}$ & $\begin{array}{l}\text { Scimago for } \\
100000\end{array}$ \\
\hline Gasto pc education & .073 & ,899 & 1 & ,602 & ,826 & ,740 & ,904 \\
\hline Sig. (bilateral) & .668 & .000 & & .000 & .000 & .000 & .000 \\
\hline Export pc & -.137 & ,710 & 602 & 1 & ,563 & ,487 & ,642 \\
\hline Sig. (bilateral) & .419 & .000 & .000 & & .000 & .002 & .000 \\
\hline Investig. (I\&D) pc & .181 & ,784 & ,826 & ,563 & 1 & 828 & ,759 \\
\hline Sig. (bilateral) & .284 & .000 & .000 & .000 & & .000 & .000 \\
\hline $\begin{array}{l}\text { Imvest por million hab } \\
\text { (NIPMH) }\end{array}$ & .102 & ,702 & ,740 & ,487 & ,828 & 1 & ,730 \\
\hline Sig. (bilateral) & .549 & .000 & .000 & .002 & .000 & & .000 \\
\hline Scimago for 100000 & .052 & ,916 & ,904 & ,642 & ,759 & ,730 & 1 \\
\hline Sig. (bilateral) & .759 & .000 & .000 & .000 & .000 & .000 & \\
\hline
\end{tabular}

One IDH input is per capita PBI. And the latter is directly and highly related to per capita spending on education, which confirms that countries that have achieved levels of development allocate more budget for education in their respective countries. So Pearson's Rho is 0.879 confirms our hypothesis.

Models have been generated that allow us to understand, what depends on the number of researchers per million people, an explanation was found. The (NIPMH) depends on PBI and research investment as a percentage of PBI. Researchers per million $=1288.34537675+2.7812350751 * \mathrm{I} \& \mathrm{D}$ investment per person. R2=0.6535, (0.0004) (0.0000) Dw (1.0298).

Now, what does the recorded scientific output in [8] per country depend on? The software has generated the following: Scientific production $=24.4+0.0544 *$ PBIpc $+0.9968 *$ GpcED. (R2= 0.8949, (0.9159) (0.0002) (0.0001) Dw (2.075951)) means that the articles published by 100 thousand in the world and accredited by [8] are explained by the PBI and per capita expenditure on education. And as you know these depend on the size of public spending that depends on the wealth of each country.

The next question has also been asked, what does investment in research and development depend on? And it was found, that it depends on the wealth by country (PBI) of the quality of life (IDH) and the of course sophisticated exports made by the country. I\&D investment $=-85005.2962607+$ $0.0295136063527 * \mathrm{PBI}+95633.8393054 * \mathrm{IDH} \quad-$ 0.0266531438077*EXPOR. R2= 0.9779, (0.001) (0.000) (0.0013) Dw (2.1916).

And the last concern was, what does the size of a country's wealth depend on with the proposed 10 variables? It was determined that it depends on education spending, and levels of I\&D investment. PBI = -2876.20676559+ $18.8401561792 *$ GEDUCA + 8.02960074926*Inves (I\&D). R2=0.9887, (0.9458) (0.0000) (0.028) Dw (1.6097).

It means that the creation of wealth depends on the expenditure in education by country and the investment in I\&D and explains it in $98.87 \%$.

Algorithm analysis $\mathrm{K}$ means. When performing the algorithms (Fig. 1) it is observed that there are three groups with quasi-similar characteristics by the observation of data.
Fig. 1 shows the 37 countries analyzed. With the software, they were grouped into three clusters. So in the conglomerate, one country remained 16, in the two, 17 countries and in the three, four countries. It can be observed that group two includes Peru and most Latin countries, which are emerging countries.

This conglomerate includes Portugal, Russia, Malaysia, Poland, Iran, among others. It should be noted that in cluster one are developed countries and in group three are Norway, Switzerland, Ireland, and Singapore. (Table VI) This last conglomerate stands out for occupying the first places in PBI per capita, in the human development index, in exports per person, which means that there are respectable reasons to accept conglomerates. Similarly, the countries of the second cluster have similar indicators and are in the last places in the ranking. The number of countries per cluster is summarized in (Table VII).

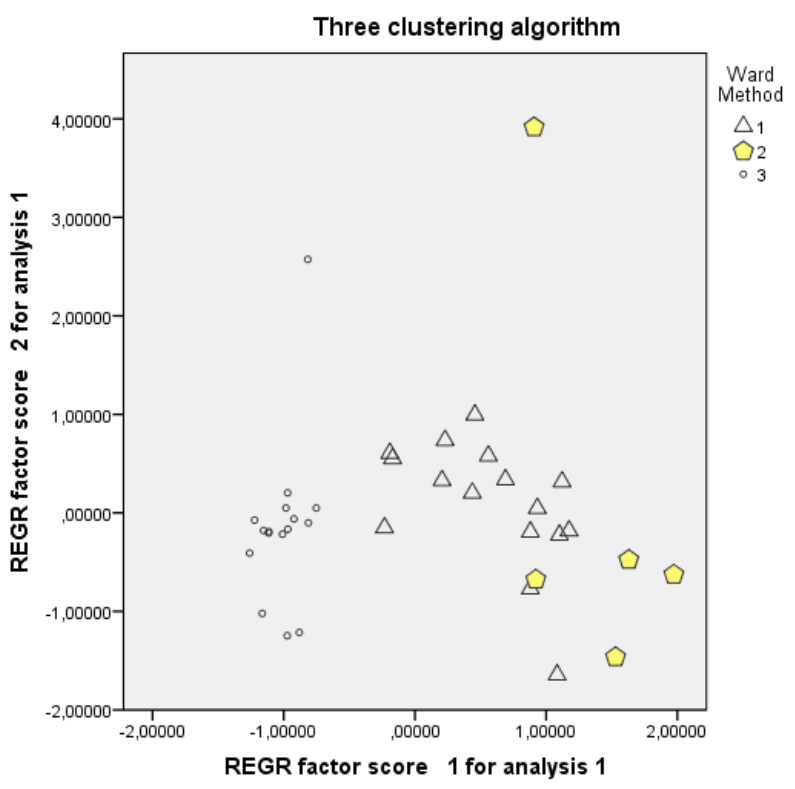

Fig. 1. Three Final Clusters. 
TABLE VI. Cluster of RELEVANCE

\begin{tabular}{|c|c|c|c|}
\hline \multirow{2}{*}{ Case } & \multicolumn{3}{|c|}{ Conglomerate clusters } \\
\hline & Countries & Cluster & Distance \\
\hline 1 & Israel & 1 & 7298 \\
\hline 2 & Corea del Sur & 1 & 14757 \\
\hline 3 & Finlandia & 1 & 4364 \\
\hline 4 & Singapur & 3 & 27735 \\
\hline 5 & Austria & 1 & 7050 \\
\hline 6 & Dinamarca & 1 & 14117 \\
\hline 7 & Japón & 1 & 9096 \\
\hline 8 & Noruega & 3 & 18434 \\
\hline 9 & Suecia & 1 & 6140 \\
\hline 10 & Estados Unidos & 1 & 19173 \\
\hline 11 & Reino Unido & 1 & 6755 \\
\hline 12 & Canadá & 1 & 2202 \\
\hline 13 & Australia & 1 & 8594 \\
\hline 14 & Portugal & 2 & 13558 \\
\hline 15 & Alemania & 1 & 4244 \\
\hline 16 & Francia & 1 & 6985 \\
\hline 17 & Suiza & 3 & 8459 \\
\hline 18 & Bélgica & 1 & 22609 \\
\hline 19 & Irlanda & 3 & 6536 \\
\hline 20 & España & 1 & 15855 \\
\hline 21 & Rusia & 2 & 2705 \\
\hline 22 & Malasia & 2 & 4555 \\
\hline 23 & Polonia & 2 & 7019 \\
\hline 24 & Italia & 1 & 12584 \\
\hline 25 & Irán & 2 & 3993 \\
\hline 26 & Turquía & 2 & 549 \\
\hline 27 & Tailandia & 2 & 2087 \\
\hline 28 & China & 2 & 1292 \\
\hline 29 & Argentina & 2 & 1389 \\
\hline 30 & Chile & 2 & 5399 \\
\hline 31 & Brasil & 2 & 1611 \\
\hline 32 & Egipto & 2 & 6332 \\
\hline 33 & México & 2 & 1603 \\
\hline 34 & Pakistán & 2 & 7279 \\
\hline 35 & Perú & 2 & 2733 \\
\hline 36 & India & 2 & 6878 \\
\hline 37 & Colombia & 2 & 3106 \\
\hline
\end{tabular}

TABLE VII. NUMBER OF CASES IN EACH CLUSTER

\begin{tabular}{|l|l|l|}
\hline Cluster & 1 & 16,000 \\
\hline Clúster & 2 & 17,000 \\
\hline Clúster & 3 & 4,000 \\
\hline Clúster & & 37,000 \\
\hline Valid &
\end{tabular}

\section{DisCussion}

The results argue that it is essential to generate wealth (PBI), to have an impact on intense expenditure on education and research, and a human capital with an attitude to propose to carry out scientific research manifested in the records of [8], which allows for greater and better exports [19] with higher.
They argue that the provision of professionals and technicians with relevant training is the crux of making economic development and quality of life sustainable, [20] (P.4) which is one of the elements in the global era of science and technology. Similarly, the World Bank [21] in 1999 noted that development is related to knowledge-based on human capital.

Another of the works that encourage to point out is when the economic resources are vital for the production of knowledge whether laboratory, or not experimental, is the one that demonstrates [22] when it states that the adequate remunerations are related to the production of knowledge.

It was not for less, since, if there are financial resources, economic, equipment, laboratories it is possibly better and more research. The relationship with the acquisition of software is highlighted, demonstrating the importance of this input. (A: 0.999). Another aspect to be taken into account is when UNESCO demonstrates and highlights the role of the institutions, their speed, their vocation, their long-term perspective to improve the elaboration of knowledge. The author in [23] (P.1), one of the determinations assumed by the author [24] is the scientific gap between countries unequal in material wealth. For the author, economic inequality and institutional factors allow for a greater gap. Per capita support is far less than decent in countries with moderate and low wealth, and skilled human resources are still a critical mass in the making. In the case of Peru, the Renacyt researchers as of March 31, 2021, are 5942.

Inequality in Latin America is increasingly difficult. Those who have managed to concentrate wealth are a smaller percentage of the population; today you can say that they define media policies, norms, and long-term policies.

It has been said that the best way to measure this situation is with the Lorentz curve [25] that designs us that decile of society has the greatest percentage of national wealth.

Discounted investment due to depreciation should be considered higher in the next period to emphasize the growth of the economy and move towards a welfare state as supported by the Harrod Domar model. That is the ingredient that longterm policies must have, for investment, and when domestic savings are lacking, then external savings must be attracted. In Peru, in reality, the pandemic has, for the time being, weakened the possibility of achieving greater human capital and of ensuring that research spending is minimal, even painful. COVID 19 has exposed the reality of research in the so-called emerging countries, today the so-called developed countries demonstrate that they are in the capacity to create the vaccine, to do experimental research, and to finance it, while the vast majority, if not 193 of the 200 countries of the world, cannot produce it because they do not have the human capital, the necessary resources and the solvency that experience gives. In any case, technology decides the leading role that imposes conditions. The global economic structure points out those countries in the second and third world must wait for vaccines to arrive. It is proven that the production function is corroborated again and again in China, Singapore, Taiwan, North Korea, Israel, England, Germany, USA, which are 
examples of the technological progress that makes faster the cumulative process of capital that generates social benefit.

In this regard [26] supports how the University of Concepción (Chile) contributes with competitive human capital, in the creation of knowledge and contribution to regional development. Chile is coping better with the pandemic.

Another work that comments on the role of universities is that of [27] who shows that actions with a view to development objectives take effect. The number of actions or activities contributed between 2016 and 2020 was 3329. Then the new production of goods and services is enriched by the application of the scientific research method to give validity and/or contribute to science and technology.

Gary Becker, has analyzed different forms of investment in the professional working in the company, in training, training, workshops, specialization and has obtained different results, [28] but all positive. The difference is in impact. [29], argue that investment in assets generates externalities that drive the economy, so that all investment is important, which is very little applied in emerging countries, and what at one stage was not considered to be the most appropriate, corrects economist Robert Lucas when he ratifies the performance of investment to generate more production, in the long run, and to grow productivity [28] is a complicated but necessary issue.

The impact of investing in human capital $(\mathrm{CH})$ and its effects on the economy was measured by economist Lucas [30], and he found that if investment in $\mathrm{CH}$ increased by $10 \%$, then the output would grow by $4 \%$. For this, developed countries inject immense resources into research and thus confirm the elasticity found is 0.4 . Although the world power, U.S. with the experience they have, the state funds the impulse in education. There can be no better example than this for emerging countries when they should fund research and the preparation of scientific tables. Providing support to accredited researchers, they do not yet do so. The data in this document shows this. Another contribution that can be derived from this work is the positive externalities that the experienced human capital contributes.

In that same direction is the contribution of [31] when it finds that if it increases by ten percent in research and development then the product would increase by between 0.6 and one percent. This is confirmed by the investigator [32]. Another author is Solow, [33] who developed the theoretical basis for explaining the factors that contribute to economic growth. The contribution was based on the technological advance and that generates the so-called aliquot of Solow, that there is a part of the economic growth that only explains it the technological advance. [34]. Experience, education, technology per person. The equation [35] was generated in application to the period between 1909 and 1949 where there were differences between the incremental rates of PNB, man-hour, and the capital factor in the period.

Thus the so-called residue was obtained. It happens that in the period the product had grown by $100 \%$, and that the capital per worker explained $12 \%$ of that difference while the remaining $88 \%$ was explained by the technological progress.
This was confirmed by Denison when analyzing the variables mentioned in the period 1929 to 1982 [36], thus also showing that education contributes to the increase of goods and services. Another argument is when the training and training provided by the company allow productivity to increase per worker [29].

At the national level from this perspective, the renowned educator has spoken [37] who with their experience defines that research has a leading role in generating knowledge but at the same time promotes methodologies and patents for increasing productivity, In that understanding, the new university law of the year 2014 rectifies the delivery of the bachelor degree without thesis.

For the same reason that it allows the generation of researchers qualified by CONCYTEC [24], the proposal is to publish in journals with peer reviewers [38]. Does a strategic direction for the development of scientific production become necessary? Of course, yes. This has to do with financing, human capital, researchers, organizational design. [39] the only way to see results in the long term. Soria adds that they can be defined as state policies [40].

\section{CONCLUSION}

It is shown that investment in I\&D has a positive relationship with higher PBI and this fulfills its cycle with greater scientific research, and vice versa.

The analysis of mean $\mathrm{K}$ determines three groups with dissimilar characteristics, based on per capita PBI, the human development index, per capita investment in research, and per capita exports. It is understood that group three countries, Switzerland, Singapore, Norway, and Ireland lead these indicators, group two being developing countries while cluster one being developed countries.

The long-term structure indicates that the circumstances have not changed in the two analysis periods, 2006 and 2019.

The educational model implemented in the conglomerate requires generating greater wealth $(\mathrm{PBI})$ to guarantee the quality of life (IDH). It is necessary to implement expenditure on education and scientific research in absolute terms.

The largest number of universities per country are concentrated where there is higher spending on education, higher investment in I\&D, where PBI is higher, where exports are differentiated products. The problem of Peru is structural and it is defined that it will be so, as long as the per capita is less than 30 thousand dollars.

\section{FUTURE WORK}

Future work will focus on comparative analysis of the behavior of the first and second waves of covid-19, a proposed model with reviews software and 2020-2021 algorithms.

Effects of the COVID-19 coronavirus on employment, family income, and digital education in Peru, 2020 - 2021 using econometric models.

Algorithms that explain the effects of COVID 19 on tax collection, private and public investment in Peru 2021. 


\section{REFERENCES}

[1] F. R. Sagasti, Tecnología, planificación y desarrollo autonomo, Primera. Lima: Instituto de estudios peruanos, 1977.

[2] S. Figueroa, G. Sánchez, and A. Vidales, La ciencia y tecnología en el desarrollo: una visión de América Latina, vol. 53, no. 9. Zacatecas: Universidad Autónoma de Zacatecas, 2009.

[3] [G. Flórez García, “Innovación en países desarrollados y subdesarrollados,” p. 58, 2020, [Online]. Available: https://repository.ucc.edu.co/bitstream/20.500.12494/16629/4/2020_Flor ez_innovacion_paises_desarrollados_subdesarrollados.pdf.

[4] Audioplayer-RPP, "Defensor del Pueblo: Estado peruano ha tenido una pésima gestión frente a la pandemia - Entrevistas ADN - RPP Noticias,” $2020 . \quad$ https://audioplayer.pe/podcast/entrevistas-adn/defensor-delpueblo-estado-peruano-ha-tenido-una-pesima-gestion-frente-a-lapandemia-6761) (accessed Apr. 17, 2021).

[5] Prensaregional, "Las pruebas rápidas no sirven... el tiempo nos da la razón | La Prensa Regional,” 2020. https://prensaregional.pe/las-pruebasrapidas-no-sirven-el-tiempo-nos-da-la-razon/ (accessed Apr. 17, 2021).

[6] H. Ritchie, "Coronavirus (COVID-19) Vaccinations - Statistics and Research - Our World in Data,” 2021. https://ourworldindata.org/covidvaccinations (accessed Apr. 17, 2021).

[7] worldmeter, "Deaths from the Coronavirus - Worldometer," 2021. https://www.worldometers.info/coronavirus/ (accessed Apr. 17, 2021).

[8] Scimago, "Scimago Journal \& Country Rank," 2021. https://www.scimagojr.com/ (accessed Apr. 17, 2021).

[9] P. Salama, "UNA Globalización Comercial Acompañada DE UNA Nueva Distribución Cartográfica,” Rev. Econ. Inst., vol. 14, no. 27, pp. 57-80, 2012, Accessed: Apr. 17, 2021. [Online]. Available: http://www.scielo.org.co/scielo.php?script=sci_arttext\&pid=S012459962012000200003\&lng=en\&nrm=iso\&tlng=es.

[10] UNESCO (UIS), “How much does your country invest in R\&D?,” 2020. http://uis.unesco.org/apps/visualisations/research-and-developmentspending/ (accessed Apr. 17, 2021).

[11] ARWU, “ARWU World University Rankings 2020 | Academic Ranking of World Universities 2020 | Top 1000 universities | Shanghai Ranking 2020," 2020. http://www.shanghairanking.com/ARWU2020.html (accessed Apr. 17, 2021).

[12] Datosmacro, "Estados Unidos - Gasto público 2019 | datosmacro.com,” 2021. https://datosmacro.expansion.com/estado/gasto/usa (accessed Apr. 17, 2021)

[13] V. Sacoto-Castillo, N. Viña-Palomino, and J. Landívar-Vera, "El aporte de la internacionalización en el desarrollo de competencias profesionales en las Universidades ecuatorianas,” Rev. Cienc. UNEMI, vol. 13, no. 33, pp. 96-107, 2020, [Online]. Available: http://ojs.unemi.edu.ec/index.php/cienciaunemi/article/view/1045/1097.

[14] J. J. Ibañez-Marti, "La Ciencia en Latinoamérica: Tendencias y patrones,” Rev. la Fac. Ciencias, vol. 7, no. 1, pp. 23-39, 2018, doi: 10.15446/rev.fac.cienc.v7n1.69409.

[15] G. M. Tóala-tóala, A. A. Mendoza-briones, and R. Cevallos-Enriquez, "Desarrollo económico: ¿ la clave para el desarrollo sostenible? Economic development: the key to sustainable development? O desenvolvimento econômico: a chave para o desenvolvimento sustentável? Resumen," Dominio las ciencias, vol. 2, pp. 432-447, 2016, [Online]. Available: ISSN 24778818.

[16] "Presión Fiscal $2020 \quad$ datosmacro.com," 2021. https://datosmacro.expansion.com/impuestos/presion-fiscal (accessed May 05, 2021).

[17] V. Quinde, R. Bucaram, M. Bucaram, and C. Silvera, "Relación entre el gasto en Ciencia y Tecnología y el Producto Interno Bruto . Un análisis empírico entre América Latina y el Caribe y el Ecuador,” Espacios, vol. 40, no. 2008, 2019.

[18] C. Clemenza, J. Ferrer, R. Araujo, and S. Espina, "Fortalecimiento de la competitividad Institucional a través de la calidad en la educación: Caso Universidad del Zulia,” Rev. Venez. Gerenc., vol. 11, no. 36, pp. 615637, 2006, Accessed: Apr. 17, 2021. [Online]. Available: http://ve.scielo.org/scielo.php?script=sci_arttext\&pid=S131599842006000400007\&lng=es\&nrm=iso\&tlng=es.
[19] W. Toledo, "El rol de las exportaciones en el crecimiento económico: evidencia de una muestra de países de América Latina y el Caribe,” Rev. Econ., vol. 34, no. 89, pp. 78-100, 2017, Accessed: Jul. 22, 2021. [Online]. Available: http://www.scielo.org.mx/scielo.php?script=sci _arttext\&pid=S2395-87152017000200078\&lng=es\&nrm=iso\&tlng=es.

[20] G. Yamada, J. F. Castro, and M. Rivera, "Educación Superior en el Perú: Retos para el Aseguramiento de la Calidad Estudio del SINEACE encargado a los especialistas,” Sist. Nac. Evaluación, Acreditación y Certificación la Calid. Educ. SINEACE, vol. 32, no. 10, pp. 1365-1367, 2012.

[21] D. I. Pérez-Fuentes and J. L. Castillo-Loaiza, “Capital humano, teorías y métodos: importancia de la variable salud,” Econ. Soc. y Territ., vol. 16, no. 52, pp. 651-673, 2016, Accessed: Apr. 17, 2021. [Online]. Available: http://www.scielo.org.mx/pdf/est/v16n52/2448-6183-est-1652-00651.pdf.

[22] V. H. Moquillaza-Alcántara, "Producción científica asociada al gasto e inversión en investigación en universidades peruanas,” An. la Fac. Med., vol. 80, no. 1, pp. 56-59, 2019, doi: 10.15381/anales.v80i1.15626.

[23] C. Cabezas Sánchez, "Rol de estado en la investigación científica en salud y transparencia en la información,” Med. Exp., vol. 23, no. 4, pp. 275-283, 2006.

[24] L. Vela Meléndez, E. R. Acevedo Sánchez, P. Yesquen Zapata, and G. Venturra Carrillo, "Ciencia, tecnología e innovación en el Perú. Necesidad de una política pública descentralista, que institucionaliza las alianzas Academia-Empresa-Estado y Sociedad Civil,” Geogr. Rev. Digit. para Estud. Geogr. y Ciencias Soc., vol. 9, pp. 138-157, 2018, doi: 10.14198/geogra2018.9.106.

[25] B. Moscoso Rojas, L. Huamán Angulo, M. Núñez Vergara, E. Llamosas Félix, and W. Pérez, "Inequidad en la distribución de recursos humanos en los establecimientos del Ministerio de Salud de cuatro regiones del Perú,” An. la Fac. Med., vol. 76, p. 35, 2015, doi: 10.15381/anales.v76i1.10968.

[26] O. Barrientos, C. Zaror, and J. Hernández, "La Universidad de Concepción y su aporte al desarrollo de la región del Biobío y el país,” Rev. Nupem, vol. 12, no. 27, pp. 180-199, 2020, doi: 10.33871/nupem.2020.12.27.180-199.

[27] C. Picado Madrigal and C. Azofeifa Ureña, Aportes de las universidades estatales costarricenses y el Conare para el logro de los Objetivos de Desarrollo Sostenible y Agenda 2030, no. 17. 2020.

[28] L. Serrano Martínez, "Indicadores de capital humano y productividad,” Rev. Econ. Apl., vol. 4, no. 10, pp. 177-190, 1996.

[29] F. L. B and J. D. Sachs, "Macroeconomía en la economía global.” p. 796, 2002.

[30] A. Rodríguez Arana, Crecimiento económico y capital humano: metodología para la simulación de una variante del Modelo de Lucas con aplicación a México, vol. 12, no. 2. Instituto Mexicano de Ejecutivos de Finanzas, A. C., 2017.

[31] Z. Griliches, "Productivity Puzzles and R\&D: Another Nonexplanation," J. Econ. Perspect., vol. 2, no. 4, pp. 9-21, 1988, doi: 10.1257/jep.2.4.9.

[32] T. J. Sargent and C. A. Sims, "Empirical Macroeconomics," Indian Econ. J., vol. 59, no. 4, pp. 3-33, 2012, doi: 10.1177/0019466220120402.

[33] A. C. Chu, Advanced Macroeconomics. 2020.

[34] G. N. Mankiw, Macroeconomics. 2010.

[35] F. Jiménez, “Macroeconomía: Enfoques Y Modelos Nuevos Ejercicios Resueltos,” PUCP, 2019.

[36] A. R. Peña Sánchez, "Human capital, investment on education and economic growth: A review and updating of regional economic asymmetry in Spain (1980-2012) | Capital humano, inversión educativa y crecimiento económico: Revisión y actualización de la asimetría económica regiona,” Rev. Estud. Reg., no. 106, pp. 21-53, 2016, [Online]. Available: https://www.redalyc.org/pdf/755/75547651002.pdf.

[37] L. Piscoya Hermoza, "Los paradigmas psicológicos como soporte científico de las tecnologías de la educación,” Rev. Investig. en Psicol., vol. 18, no. 1, p. 139, 2016, doi: 10.15381/rinvp.v18i1.11783.

[38] M. A. Bunge, "El planteamiento científico,” Rev. Cuba. Salud Pública, vol. 43, no. 3, pp. 1-29, 2017. 
[39] L. Pedraja-Rejas and E. Rodríguez-Ponce, "La relevancia del proyecto estratégico como determinante de la calidad en las universidades," Idesia (Arica), vol. 32, no. 4, pp. 101-103, Nov. 2014, doi: 10.4067/S071834292014000400013.
[40] O. Soria, "Descentralización Educativa Título: El dilema entre saber, poder y querer . ¿ Una nueva universidad para el siglo XXI ?," Rev. Iberoam. Educ., vol. 3, p. 14, 1994. 